\title{
THE CONTRIBUTION OF CO-OPERATIVE EDUCATION IN THE GROWING OF TALENT IN SOUTH AFRICA: A QUALITATIVE PHENOMENOLOGICAL EXPLORATION
}

\author{
THOMAS GROENEWALD \\ WILLEM SCHURINK \\ Programme in Leadership in Performance and Change \\ in the Department of Human Resource Management \\ Rand Afrikaans University
}

\begin{abstract}
Organisational talent is internationally regarded a key success factor in a competitive world and is continuously challenged. In South Africa, the Apartheid heritage further presents major challenges regarding developmental opportunities of talented people. Co-operative education presents, as structured educational strategy that progressively integrates academic study with learning through productive work experiences, itself as a means to grow the talent of the South African people. As result of the inadequate practice of co-operative education and a fair amount of associated resistance, 'classical' literature is reviewed. The literature review further identifies the core properties of co-operative education and the study has attempted to distil the core principles of a phenomenological research design. The specific 'phenomena' which the research focused on are existing joint ventures between Higher Education institutions and business enterprises aimed at educating people and growing talent. Selections of the voices of the research participants are presented in this article. Although the present study identifies several shortcomings regarding the practice of co-operative education, it pioneers the notion that the growing of talent can be enhanced through a co-operative education strategy.
\end{abstract}

\section{OPSOMMING}

Organisatoriese talent word internasionaal beskou as 'n sleutelfaktor in 'n kompeterende wêreld en word dus voortdurend aan uitdagings onderwerp. In Suid Afrika stel die nagevolge van Apartheid grootskaalse uitdagings ten opsigte van die ontwikkelings moontlikhede van talentvolle mense. Koöperatiewe onderwys bied, as gestruktureerde opvoedkundige strategie wat progressief akademiese leer met produktiewe werkservaring integreer, 'n geleentheid om die talent van Suid-Afrikaners op te bou. 'Klasieke' literatuur word weegegee ten einde die ontoereikende beoefening van koöperatiewe onderwys en 'n gepaartgaande redelike mate van weerstand aan te spreek. Die literatuurstudie identifiseer verder die kerneienskappe van koöperatiewe onderwys en probeer om die vernaamste eienskappe van 'n fenomenologiese studie raak te vat. Die spesifieke 'fenomene' waarop die studie fokus, is die bestaande samewerking tussen tersiêre instellings en besigheidsondernemings om mense op te lei en hul talent te ontwikkel. Geselekteerde uitsprake van die deelnemers aan die studie word weergegee en alhoewel daar verskeie tekortkominge rakende die beoefening van koöperatiewe onderwys geïdentifiseer is, verteenwoordig die studie baanbrekerswerk op die terrein van die rol van koöperatiewe onderwys in die ontwikkeling van talent.

The Centre for Work Performance (Rand Afrikaans University, 2002) identified, among a number of current issues for debate, the need for "effectively attracting, growing and retaining talent" (emphasis added). Figura (2000), HRfocus (2001) and Johnson (2000) share the view that retaining the correct mixture of human talent ensures a competitive advantage. It is recognised internationally (HRfocus, 2001; Johnson, 2000; Liebmann, 2000; Ridderstråle and Nordström, 2000; Vicere, 1991; Ziarati et al., 1995) that the talent of people is a key success factor in global competitiveness.

During the past decade major changes have taken place in the corporate landscape, such as globalisation, aggressive competition and cross-penetration of markets, as well as the introduction of virtual work teams (Barner, 2000). These changes have impacted drastically on the talent life cycle of enterprises: turnover of talent has been affected; totally new or different talent requirements have emerged and enterprises have experienced difficulty in recruiting and retaining talent. Cataldo et al. (2000, p. 55) remark that the "current skills sets are proving to be inadequate to meet the rapidly changing fast-paced world of technical and business needs". HRfocus (2001, p. 14) reports that "eighty percent of white collar jobs would be obsolete in five years". Because of the birth of new first-time technologies and competitors emerging from unexpected fields (Barner, 2000), leading enterprises experience a need

Requests for copies should be addressed to: T Groenewald, Department of Human Resource Management, RAU University, PO Box 524, Auckland Park, 2006 for new talent to staff 'jobs' that did not previously exist. In this regard Cataldo et al. (2000) remark that it is no longer strange to lay off people, in order to eliminate obsolete positions, while simultaneously hiring people to acquire new talent.

Not only is there some doubt concerning talent as an inborn gift (Simonton, 2001; Sunoo, 2001), but is the need for developing latent talent largely uncontested (Bals, 1999; Lunn, 1995; Mayo, 2000). Because of the fierce competition in attracting and retaining talent, prudent enterprises proactively develop leadership and grow talent to ensure a best-in-class workforce (cf. Barner, 2000; Figura, 2000; Friedland, 2000 Greene, 2000; Hammett, 2001; Matthew, 2000; McDonald, 1999; Seligman, 2000; Shoebridge, 2000; Tulgan, 2001; United States of America, 2000; Voros, 1999; Way, 2000). While the individual's responsibility is emphasised (cf. El-Tannir, 2000 Greene, 2000; Johnson et al., 1999; Maloka, n.d.; Radebe, 2001; Seligman, 2000), the duty of employers (El-Tannir, 2002; Garavan et al., 2001; Johnson, 2000) is also crucial if they wish to attract and retain talent. Mentoring programmes (cf. Conway, 1995; Johnson et al., 1999; Managers Handbook, 1997), graduate programmes (cf. Cross, 1999; Doherty et al., 1997; Smith \& Smith, 1990) and mutually advantageous partnerships with education providers (cf. Barnes \& Phillips, 2000; Berkeley, 1998; Blackburn \& Fryer, 1996; Brindley \& Ritchie, 2000; Davies, 1998; Dealtry, 2001; Doncaster, 2000; Gericke, 2001; Rosenbaum, 2000; Sandelands, 1998; Stephen et al., 1997; Teare, 2000; Ziarati et al., 1995) are further prominent in literature. 
The need for growing the talent of people in South Africa The report of the Black Economic Empowerment Commission (BEE Com., 2001, p. 13) states "Colonial and Apartheid policies had a devastating impact on the development of black human capital". This neglect of part of South Africa's "most important economic resource - its people" will for a long time restrict the potential growth rate and will render many South African enterprises less competitive. In this regard Ziarati et al. (1995) observe that for enterprises to continue to prosper in the international marketplace, where competition is fierce, enterprises can no longer afford mediocrity. In other words the situation presents a major challenge to both education providers and to enterprises to grow or develop the talent of South Africans. BEE Com. (2001, p. 17) argues the need for "an integrated National HRD [Human Resource Development] Strategy" published in April 2001, i.e. the Human Resource Development Strategy for South Africa - A Nation at Work for a Better Life for All (Republic of South Africa, 2001).

Mulemfo (2000) highlights the need for growing talent in view of the lagging productivity in South Africa and in Africa as a whole. He asserts that low productivity is evident and cites examples such as workers sitting idle when the boss is absent; teachers chatting rather than doing their work; a variety of illnesses invented by government officials to miss work; and go-slow attitudes promoted by unions. Mulemfo (2000, p. 90) submits that "people who will work hard to produce more" are needed.

Hadland and Rantao (1999, p. 135) capture the need for growing talent in South Africa by quoting the profound words of Patti Waldmeir subsequent to the first democratic elections of 1994: "(the country) emerged in the real world, where poverty is the biggest challenge to all democratic governments, and where there are tougher problems to solve than apartheid". Hadland and Rantao (1999) conclude that the more than 50 years of apartheid marginalised and disempowered black people. South Africa shares this predicament of decolonisation and deracialisation with the rest of Africa, according to Mamdani (1999).

This idea of the socio-economic legacy of apartheid was referred to by President Thabo Mbeki's 'Two Nations' speech of 29 May 1998. In this regard Mamdani (1999, p. 126) observes that "if white South Africa were a country on its own, its per capita income would be 24th in the world, next to Spain; but if black South Africa were a separate country, its per Capita income would rank 123rd globally, just above the Democratic Republic of the Congo". Mamdani (1999, p. 129) appealing for "an intellectual rebirth, a reawakening of the mind"; further asserts: "renaissance is first and foremost a reawakening of thought" (p. 130) and claims that the driving force "is inevitably the intelligentsia".

According to the article "Education for an 'African Renaissance" (2000, p. 14) "education is the sine quo non for empowering the people of Africa to participate in and benefit more effectively from the opportunities available in the globalised economy of the $21^{\text {st }}$ century". James (1997) cautions that the Renaissance in South Africa must not be simply celebrated as an event or serve as symbolic rhetoric (cf. Fourie, n.d.; Maloka, n.d.) or merely represent hopes and ideals (University of Witwatersrand, 1999). The African Renaissance must be carefully nurtured in order to succeed. Fourie (n.d.), Mbeki (1998a, 1998b), Netshitenzhe (1998), Radebe (2001) and the African Renaissance and International Co-operation Fund Act (Republic of South Africa, 2000) emphasise factors such as the importance of good education and human development to succeed in the immense challenge.

Maloka (n.d.) refers to an article by Vusi Maviembela, President Mbeki's political advisor. He portrayed the 'African Renaissance' as the third moment in the post-colonial history, after decolonisation and the democratic upsurge of the 1990s. Kofi Annan, Secretary General of the United Nations, according to James (1997), refers to three waves similar to these moments. The second wave was marked by civil wars, tyranny of military rule and economic stagnation.

The key elements, according to Maloka (n.d.) of the 'African Renaissance' are socio-political democratisation, economic regeneration and improvement of geopolitical standing in world affairs. These elements represent a globalist perspective. Further perspectives are the Pan Africanist perspective (Pax Africana: African problems solved by African solutions) and a culturalist perspective (an ethnophilosophy of returning to the roots of the people of Africa).

\section{Co-operative education and the growing of talent}

Co-operative education is an educational philosophy that advocates the formal integration of work experience (or community service) into the theoretical curriculum (Pratt, 1996). Cates and Jones (1999) define co-operative education as a structured educational strategy that progressively integrates academic study with learning through productive work experiences in a field related to a student's academic or career goals. This experiential learning is not an add-on to the curriculum, but an integral part of the educational process. Cooperative education presents itself as a means to grow the talent of the South African people.

A large degree of conceptual drift of the construct co-operative education occurred. It is therefore necessary to revisit the literature of the inception years and to let those voices speak. These voices were chosen to give authenticity and are interwoven with more contemporary views. On 26 January 1914 Schneider, Dean of the College of Engineering of the University of Cincinnati, appeared before the Committee of Education of the House of Representatives in Washington, and stated (United States of America, 1914, pp. 3-5, 9) among others the following regarding the 'Cooperative System of Education':

\section{"[T]he cooperative system aims to tie theory and practice} together directly.

[T] he student completes all the ... courses ... necessary to the obtaining of a ... degree, and he [or she] also finishes his apprenticeship course in the practical field ... This apprenticeship course in the practical work is arranged by the university, and is just as carefully worked out as his university curriculum.

The theoretical work in the university and the practical work in the commercial field are coordinated by a number of devices, but principally by the use of teachers whom we call coordinators.

[T] he theory and practice are made to work hand in hand so that the practical work has the highest possible educational value.

The practical work is just as carefully arranged as the college curriculum.

Every detail of the practical course is carefully arranged and practice and theory are knit together in a uniform scheme through a carefully devised system of coordination.

The function of this [coordination] department is to see that an intimate tie is established between the theory and practice and to check and counter check this tie.

In this way the outside practical work is made of great educational value." (Emphasis added.)

Regrettably "Schneider left no comprehensive statement of the philosophy of the co-operative system" (Freund, 1947, p. 13). However, he did leave a heritage of success in education. Eshbach (1947, p. 18) remarks that "[w]hen properly done, 
there is no better or more effective method than co-operative education for professional vocations". He suggests that the Latin motto 'experimentia docet' (experience teaches), forms the heart of co-operative education. Eshbach (1947, p. 19) observes that Schneider's innovative contribution was the "taking of the student to industry, where experience and practice can be observed in a more natural state" (emphasis added).

The nucleus of Schneider's philosophy is balanced training, i.e. "theory comes first, both as to time order and as to emphasis" (p. 10) followed by "hard contact with life" (p. 11, emphasis added in both cases) and comprehension of the workings of things where they operate. In this regard Geier $(1947$, p. 25), President of the Cincinnati Milling Machine Company, corroborates that "[c]o-operative education seeks to weld theoretical knowledge and practical experience into the most effective tool for today's work" (emphasis added). According to Ellison (n.d.) this new teaching methodology changed twentieth-century education. Only when students began to apply the theory to practice did their minds start to ask questions, suggesting a need or motivation for deeper learning (Langford \& Cates, 1997). Schneider further became convinced that many professional concepts and skills could only be understood and mastered through actual work experience (University of Cincinnati, 1998, 1996).

Charles Kettering, a strong advocate of co-operative education, research director of General Motors Corporation and chair of the Thomas Alva Edison Foundation, initiated the documenting of evidence of co-op's educational value. This resulted in a publication 'Work-Study College Programs' in 1961, which attributed many educational benefits to co-operative education (Sovilla, 1998). With regard to the educational value and educational benefits Ferris (1969, p. 482) highlights the following key advantages:

First its impact on the curriculum. It not only provides the occasion for making changes that have been put off because they require too much work, time, and money, but once a programme is going, a new kind of interplay is set up between campus and community that gives the curriculum a dynamic quality. Students bring something back into the classroom. They confront questions and problems that would not have occurred to them in the classroom alone and bring them back looking for answers and solutions. In the process, the gap between theory and practice narrows. And because practice keeps changing, theory is kept to the test.

The second side advantage is that private industry is brought into the educational process in a meaningful rather than patronizing way. ... coordinating a cooperative education program is no simple task, placing students has not been a major problem. The job market - in many ways the most critical aspect of all - has been excellent. (Emphasis added.)

From the excerpts above it is evident that in the late 1960s the educational paradigm co-operative education resulted in a dynamic programme curriculum as well as an interaction between the Higher Education institution and its community. Learners enjoyed the benefit of workplace learning in addition to their formal studies. The job market was seen as a critical aspect and the involvement of private industry in the educational process was emphasised.

Smith and Lancaster $(1995$, p.1) remark: "[a] recurrent theme in the co-op literature is the identification of strategies for integrating cooperative education into the 'academic mainstream' of colleges and universities". They observe the persistence of this theme since 1980. In this regard the Accreditation Council for Cooperative Education (n.d. Web Page) also emphasises faculty involvement as one of the required attributes of co-operative education programmes at colleges and universities.
The original goal of co-operative education was to enhance student learning. Sovilla (1998) remarked that the leaders of many institutions do not seem to appreciate the mission of cooperative education or else choose to ignore it. The coordinating and administrative support service must be an integral part of the academic programme that aids the achievement of the curriculum outcomes. However, Kerka (1999) cautions that too much emphasis is placed on job placements instead of learning and calls for a redesign and/or reconceptualisation of co-operative education (i.e. learning from work experience integrated into the curriculum). Kerka (1999) as well as Wilson, Stull and Vinsonhaler (1996) suggest a fresh perspective and definition of co-operative education as a curriculum model, affirming work-based learning and based on sound adult learning theories and principles such as self-directed learning, reflective learning/practice and transformative learning. Duwart and Canale (1997) recommend a three-phase educational process, i.e. preparation, experience and reflection. However, Finn (1997) suggests it is necessary to go beyond reconceiving to adopting co-operative education as educational strategy.

Furco (1996) and Kerka (1999) indicate that although service learning (learning derived from rendering services related to the course of study) and co-operative education have different goals the following apply to both: active engaging in meaningful work renders the best learning; active learners produce knowledge; contextual learning in real situations as instructional strategy; integration of the two forms of learning; and formal partnerships with real-life learning providers. Kerka (1999, p.3) declares that partnerships should be developed into a supportive culture where "employer support does not have to be repeatedly obtained and there are clearly understood long-term expectations". The Accreditation Council for Cooperative Education (n.d. Web Page) furthermore emphasises employer involvement as one of the required attributes of co-operative education programmes and Reuss (2001) declares partnerships a key component.

In essence, the construct co-operative education can be reduced to three core dimensions: (a) the integrated curriculum, (b) learning derived from work experience and (c) the logistical organisation and co-ordination of the learning experience.

The research question(s) and the study's aim

The aim of the study is to demonstrate the value of cooperative education in the growing of people talent. The specific phenomenon forming the focus of this study is the existing joint ventures between Higher Education institutions and business enterprises in order to educate people and grow talent. The study's central research question is: what is the contribution that co-operative education can make, in the growing of talent of the South African people? Bentz and Shapiro (1998) and Kensit (2000) caution that the researcher must allow the data to emerge: "Doing phenomenology" means capturing "rich descriptions of phenomena and their settings" (p. 104). For this reason the actual research questions that were put to participants (both academics and enterprise representatives involved) were phrased as follows:

- How did/do you experience the joint educational venture?

- What value, if any, has been derived from the collaborative effort?

Kvale (1996) draws a similar distinction between the research question and the interview question. It is important to keep in mind that the findings may, or may not, illustrate that the practice of co-operative education contributes to the growing of talent. In this regard Jon Kabat-Zinn, referenced by Bentz and Shapiro $(1998$, p. 39) state that "inquiry doesn't mean looking for answers". 


\section{METHOD}

We decided upon a qualitative research design in order to achieve the goal of this study. The type of qualitative research requires determines the research design (cf. Creswell, 1998; Mason, 1996). However, researchers are not restricted to any one pure approach but may blend different approaches and metaphorically weave a fabric comprising a variety of threads, colours, textures and blends (Creswell, 1998), thus blurring the disciplinary boundaries (Schurink, 2002a).

\section{Research paradigm}

In view of the plethora of qualitative research designs, it is advisable for a qualitative researcher to qualify her/his scientific beliefs and research paradigm, i.e. what constitutes her/his ontology (beliefs and perceptions about the nature of reality), her/his epistemology (where the researcher stands in relation to reality and in which way s/he will go about searching for truth) and her/his methodology (the methods and techniques that will be used to research reality) to those with an interest in the research (Denzin \& Lincoln, 1998; Mason, 1996; Schurink, 2002b). Creswell $(1994,1998)$ as well as Denzin and Lincoln (2000) add a fourth concept, i.e. the researcher's axiology (i.e. ethics and values). This concept is particularly important since it differs from quantitative research endeavours, which claim to be value-free and unbiased, in that qualitative research is valueladen and biased.

From an ontological position or perspective, qualitative researchers believe that reality is constructed by individuals, i.e. different personal versions of the nature and the essence of things (Mason, 1996). A multitude of realities therefore exists. Creswell (1994, p. 4) observes that "[f]or the qualitative researcher, the only reality is that which is constructed by the individuals involved in the research situation". The researcher is dependent upon the voices (quotes and themes in words) and informant or participant interpretations to understand a given reality (Creswell, 1994, 1998).

The ontological dimension of the study is the sub-discipline of human resource development, more especially leadership in performance and change. Within the study there is, further, an overlap with education as a discipline. Generally individuals are held responsible for the growth of their own talent. However, planned and co-ordinated educational programmes, especially those, which alternate theoretical learning with real-life application, result in synergy, i.e. the whole is more than the sum total of the parts. The value that an individual will derive from an educational programme is dependent on her/his own efforts and abilities, as well as the management of the programme. The value that is derived is further influenced by the extent to which the curriculum succeeds in integrating theory with real-life application.

A researcher's epistemology according to Creswell (1994), Mason (1996) and Holloway (1997) is literally her/his theory of knowledge, which serves to decide how the social phenomenon will be studied. Our epistemological position can be formulated as: (a) data are contained within the perspectives of people that are involved with co-operative education programmes, either in a co-ordinating capacity or as programme participant, and (b) because of this we engaged with the participants in collecting the data.

A phenomenological methodology was identified as the best means for this type of study. Phenomenologists, in contrast to positivists, believe that the researcher cannot be detached from her/his own presuppositions and that the researcher should not pretend otherwise (Hammersley, 2000). In this regard Mouton and Marais (1990, p. 12) state that individual researchers "hold explicit beliefs". The intention of this research, at the onset (preliminary focus), is to gather perspectives regarding the phenomenon of the growing of talent and the contribution of co-operative education to this process.

\section{Phenomenology}

According to Giorgi (Stones, 1988, p. 143) the operative word in phenomenological research is 'describe'. The aim of the researcher is to describe as accurately as possible the phenomenon while refraining from any pre-given framework, but staying true to the facts. According to Welman and Kruger (1999, p. 189) "phenomenologists are concerned with understanding social and psychological phenomena from the perspectives of people involved". A researcher applying phenomenology is concerned with the lived experiences of the people (cf. Greene, 1997; Holloway, 1997; Kruger, 1988; Kvale, 1996; Maypole \& Davies, 2001; Robinson \& Reed, 1998) involved, or who were involved, with the issue being researched. The words of Van den Berg, translated by Van Manen (1997, p. 41) profoundly capture what is stated in this paragraph:

[Phenomena] have something to say to us - this is common knowledge among poets and painters. Therefore, poets and painters are born phenomenologists. Or rather, we are all born phenomenologists; the poets and painters among us, however, understand very well their task of sharing, by means of word and image, their insights with others - an artfulness that is also laboriously practised by the professional phenomenologist.

\section{Locating the research participants}

According to Hycner (1999, p. 156) "the phenomenon dictates the method (not vice-versa) including even the type of participants". Purposive sampling was chosen in determining the primary participants: the sample was based on our judgement and the purpose of the study (cf. Babbie, 1995; Greig \& Taylor, 1999; Schwandt, 1997), i.e. those who "have had experiences relating to the phenomenon to be researched" (Kruger, 1988 p. 150). We identified the programme managers at Higher Education institutions in the South African Province of Gauteng, who are responsible for educational programmes that are tailored to the needs of and offered in collaboration with commerce, industry and/or government. Interviews were arranged with these programme managers. These interviewees, with their 'informed consent' (Bailey, 1996, p. 11; Arksey \& Knight, 1999; Street, 1998) are the primary unit of analysis (Bless \& Higson-Smith, 2000).

In order to trace additional participants or informants, we used snowball sampling: a method of expanding the sample by asking one informant or participant to recommend others for interviewing (Babbie, 1995; Miller \& Crabtree, 1992). The purposefully selected interviewees were requested to give, at their discretion, the names and contact details of persons based in commerce, industry and/or government who (a) were co-responsible for the educational programmes and (b) who had participated in the programme presented.

Because Creswell (1998, pp. 65 \& 113) recommends "long interviews with up to 10 people" for a phenomenological study, a sample size of ten managers, five responsible for educational programmes and five at collaborating enterprises, were selected. In addition to the ten interviewees, one group of programme participants (learners or students) was requested to write essays on their experiences. With another group of programme participants some participated in a focus group discussion, while others wrote essays. The purpose of collecting data from three different kinds of informants was to effect a form of triangulation, i.e. 'data triangulation' to contrast the data and 'validate' the data if it yields similar findings (cf. Arksey \& Knight, 1999; Bloor, 1997; Holloway, 1997). 


\section{Procedure}

Unstructured in-depth phenomenological interviews were conducted with both the educational institution-based programme managers and with the enterprise-based representatives. These interviews were conducted as follows: our questions were "directed to the participant's experiences, feelings, beliefs and convictions about the theme in question" (Welman \& Kruger, 1999, p. 196). Husserl according to Bentz and Shapiro (1998, pp. $41 \&$ 96), called it bracketing where the inquiry is performed from the perspective of the researcher. Bracketing (Caelli, 2001; Davidson, 2000; King, 1994; Kruger, 1988; Kvale, 1996) in this study entailed asking the participants or informants to set aside their experiences about the collaborative educational programme and to share their reflection on its value. Data were obtained about how the participants "think and feel in the most direct ways" (Bentz \& Shapiro, 1998, p. 96). We focused on "what goes on within" the participants and got the participants to "describe the lived experience in a language as free from the constructs of the intellect and society as possible". This is one form of bracketing. There is also a second form of bracketing, which, according to Miller and Crabtree (1992, p. 24) is about the researcher that "must 'bracket' her/his own preconceptions and enter into the individual's lifeworld and use the self as an experiencing interpreter".

Kvale (1996, pp. 1-2) remarks with regard to data capturing during the qualitative interview that it "is literally an inter view, an interchange of views between two persons conversing about a theme of mutual interest". The researcher attempts to "understand the world from the participants' point of view, to unfold meaning of peoples' experiences". At the root of phenomenology "the intent is to understand the phenomena in their own terms - to provide a description of human experience as it is experienced by the person herself" (Bentz \& Shapiro, 1998, p. 96) and allowing the essence to emerge (Cameron, Schaffer \& Hyeon-Ae, 2001). The maxim of Husserl was 'back to things themselves!' (Kruger, 1988, p. 28).

In addition to the ten interviews conducted in this study, the educational institution-based programme managers in two instances arranged access to programme participants. Depending on the circumstances, Groenewald either talked directly to the programme participants and asked them to write essays or worked through the programme manager and presented the following request:

Write down your viewpoints, perspectives or feelings of the programme you are undergoing, or have completed. You need not give your name. You need not concern yourself with grammar or spelling. If possible, compare this programme with others you may have done, which are not offered through collaboration between an employer and an educational institution (or purely academic programmes known to you from talking to other students).

\section{Explicitation of the data}

The phenomenological explicitation process that we used comprises five stages:

(a)Bracketing and phenomenological reduction. The term reduction, coined by Husserl, is regarded by Hycner (1999) as unfortunate, because it has nothing to do with the reductionist natural science methodology. It would do a great injustice to human phenomena through over-analysis, removal from the lived contexts of the phenomena and worse possibly reducing phenomena to cause and effect. Phenomenological reduction "to pure subjectivity" (Lauer, 1958, p. 50), instead, is a deliberate and purposeful opening by the researcher to the phenomenon "in its own right with its own meaning" (Fouche, 1993; Hycner, 1999, p. 144). It further points to a suspension or 'bracketing out' (or epoche), "in a sense that in its regard no position is taken either for or against" (Lauer, 1958, p. 49), the researcher's own presuppositions and not allowing the researcher's meanings and interpretations or theoretical concepts to enter the unique world of the informant/participant (Creswell, 1998, pp. 54 \& 113; Moustakas, 1994, p. 90; Sadala \& Adorno, 2001). This is a different conception of the term bracketing used when interviewing to bracket the phenomenon researched for the interviewee. Here it refers to the bracketing of the researcher's personal views or preconceptions (Miller \& Crabtree, 1992).

Based on Holloway (1997, p. 119) and Hycner's (1999, p. 145) recommendation, Groenewald repeatedly listened to the audio recording of each interview in order to become familiar with the words of the interviewees/participants and to develop a holistic sense, the 'gestalt'. Zinker (1978, p. 77) explains that the term phenomenology implies "that process which one experiences as uniquely one's own; adding the dimensions of here and now gives personal phenomena existential immediacy".

(b)Delineating units of meaning. This is a critical phase of explicating the data, in that those statements that are seen to illuminate the researched phenomenon are extracted or 'isolated' (Creswell, 1998; Holloway, 1997; Hycner, 1999). The researcher is required to make a substantial number of judgement calls while consciously bracketing her/his own presuppositions in order to avoid inappropriate subjective judgements.

Groenewald carefully scrutinised the list of units of relevant meaning that were extracted from each interview and eliminated the clearly redundant units (Moustakas, 1994). To do this he considered the literal content, the number (the significance) of times a meaning was mentioned and also how (non-verbal or para-linguistic cues) it was stated. The actual meaning of two seemingly similar units of meaning might be different in terms of weight or chronology of events (Hycner, 1999).

(c) Clustering units of meaning to form themes. With the list of non-redundant units of meaning in hand Groenewald again bracketed his presuppositions in order to remain true to the phenomenon. A rigorous examination of the list of units of meaning followed and he elicited the essence of meaning within the holistic context. Hycner (1999) remarks that this calls for even more judgement and skill on the part of the researcher. Colaizzi, quoted by Hycner (1999, pp. 150-151), makes the following remark about the researcher's 'artistic' judgement here: "Particularly in this step is the phenomenological researcher engaged in something which cannot be precisely delineated, for here he is involved in that ineffable thing known as creative insight".

Clusters of themes were formed by grouping the units of meaning together (Creswell, 1998; King, 1994; Moustakas, 1994) and significant topics identified, also called units of significance (Sadala \& Adorno, 2001). Both Holloway (1997) and Hycner (1999) emphasise the importance of the researcher returning to the recorded interview (the gestalt) and forth to the list of non-redundant units of meaning to derive clusters of appropriate meaning. There were several overlaps in the clusters, which can be expected, considering the nature of human phenomena. By interrogating the meaning of the various clusters the central themes were determined, "which expresses the essence of the cluster" (Hycner, 1999, p. 153).

(d)Summarise each interview, validate and modify. A summary that incorporates all the themes elicited form the data gives a holistic context. Ellenberger, quoted by Hycner (1999, pp. 153-154), captures it as follows:

Whatever the method used for a phenomenological analysis the aim of the investigator is the reconstruction of the inner world of experience of the participant. Each individual has his own way of experiencing temporality, spatiality, materiality, but each of these coordinates must be understood in relation to the others and to the total inner 'world'. 
At this point Groenewald conducted 'validity checks' and returned the 'analyses' to the participants to determine if the essence of the interview has been correctly 'captured' (Hycner, 1999, p. 154). A few modifications were done as result of this 'validity check'.

(e) General and unique themes for all the interviews and composite summary. After the process outlined from (a) to (d) was completed for all the interviews Groenewald looked "for the themes common to most or all of the interviews as well as the individual variations" (Hycner, 1999, p. 154). Care was taken not to cluster common themes if significant differences existed. The unique or minority voices are important counterpoints to bring out regarding the phenomenon researched.

Groenewald concluded the explicitation by writing a composite summary, which reflects the context or 'horizon' from which the themes emerged (Hycner, 1999, p. 155; Moustakas, 1994, p. 97). According to Sadala and Adorno (2001, p. 289) the researcher, at this point "transforms participants' everyday expressions into expressions appropriate to the scientific discourse supporting the research". However, Coffey \& Atkinson (1996, p. 139) emphasise that "good research is not generated by rigorous data alone ... [but] 'going beyond' the data to develop ideas". Initial theorising, however small, is derived from the qualitative data.

\section{RESULTS}

The results of this study reflects the views of a considerable range of fields or disciplines, which is summarised in Table 1. Capital alphabet letters are used in Table 1 for ethical reasons, i.e. to protect the identity of participants and their employers. The same alphabet letters hereafter serve to identify the voices of relevant participants.

\section{TABLE 1}

THE RANGE OF PARTICIPANTS INTERVIEWED

\begin{tabular}{|c|c|}
\hline $\begin{array}{l}\text { Educational institution based } \\
\text { interviewees represented the } \\
\text { following fields or disciplines: }\end{array}$ & $\begin{array}{l}\text { Commerce, industry and/or } \\
\text { government based interviewees } \\
\text { represented the following fields or } \\
\text { disciplines: }\end{array}$ \\
\hline $\begin{array}{l}\text { A. Human resources/personnel } \\
\text { management and general middle } \\
\text { management education. }\end{array}$ & $\begin{array}{l}\text { F. General management development } \\
\text { for local government. }\end{array}$ \\
\hline B. Project management. & $\begin{array}{l}\text { G. Commercial and financial } \\
\text { accounting services. }\end{array}$ \\
\hline $\begin{array}{l}\text { C. Senior and middle general } \\
\text { management development. }\end{array}$ & H. Construction and civil engineering. \\
\hline $\begin{array}{l}\text { D. Marketing and management } \\
\text { sciences. }\end{array}$ & $\begin{array}{l}\text { I. Science, technology, engineering } \\
\text { and minerals research. }\end{array}$ \\
\hline E. Information technology. & $\begin{array}{l}\text { J. Travel, tourism and public } \\
\text { transportation. }\end{array}$ \\
\hline
\end{tabular}

\section{Composite summary}

A wide spectrum of perspectives was found regarding the phenomenon of joint educational ventures and the perceived value derived from such collaborative efforts. Among others, the significant role of mentors and the importance of a suitable mentor supervising work-based learning stood out. Associated with this was the importance of commitment by employers and the capacity to devote managerial energy. However, difficulty is generally experienced in finding sufficient suitable experiential learning opportunities. There is a perception that experiential learning does not add value because of its deficiencies and the constraints experienced regarding its proper management. However, based on the good results derived from in-service training and satisfaction with the integration of theory and practice, we encountered an opposing perspective. Learnerships as element of the national skills development strategy were further perceived important and contributing to society at large. Another important perspective was the required responsiveness by educational institutions to the needs of enterprises. Although some educational partnerships tailored to organisational needs existed, the failure of educational institutions and inflexibility of partnerships were also prevalent.

\section{Unique themes}

The composite summary above only reflects the themes that are common to most or all of the interviews. As already indicated individual variations or unique themes (Hycner, 1999) are equally important. Several themes emerged from this study, which are reflected in Table 2 . The themes that emerged are in column 1 in the table and the research participants from which the themes originated are indicated with ticks in the relevant columns.

TABLE 2

THE SCOPE OF THE QUALITATIVE DATA COLLECTED

\begin{tabular}{|c|c|c|c|c|c|c|c|c|c|c|}
\hline \multirow[t]{2}{*}{ Themes that emerged } & \multicolumn{10}{|c|}{ Research participants (see table 1 ) } \\
\hline & A & B & $\mathrm{C}$ & D & E & F & G & $\mathbf{H}$ & I & $\mathrm{J}$ \\
\hline $\begin{array}{l}\text { Curriculum adaptation to fit } \\
\text { corporate needs is enabled by } \\
\text { collaboration between Higher } \\
\text { Education institutions and } \\
\text { enterprises. Formal bureaucracy } \\
\text { disempowers, whereas } \\
\text { entrepreneurial freedom empowers. }\end{array}$ & $\checkmark$ & & & & & $\checkmark$ & $\checkmark$ & & & $\checkmark$ \\
\hline $\begin{array}{l}\text { The functioning of advisory } \\
\text { committees leaves a lot to be } \\
\text { desired. }\end{array}$ & & $\checkmark$ & & & $\checkmark$ & & $\checkmark$ & $\checkmark$ & & \\
\hline $\begin{array}{l}\text { The benefits of learning from work } \\
\text { placements are undermined as a } \\
\text { result of a lack of opportunities } \\
\text { and support from providers. }\end{array}$ & & $\checkmark$ & & $\checkmark$ & $\checkmark$ & & & & & \\
\hline $\begin{array}{l}\text { Views varied regarding the } \\
\text { certification of in-service training } \\
\text { providers. Monitoring of } \\
\text { experiential learning providers } \\
\text { seems problematic. Structured in- } \\
\text { house programmes appear to } \\
\text { work fine. }\end{array}$ & & & $\checkmark$ & $\checkmark$ & & $\checkmark$ & $\checkmark$ & & $\checkmark$ & $\checkmark$ \\
\hline $\begin{array}{l}\text { A 'talent pool' is formed by offering } \\
\text { in-service training programmes. }\end{array}$ & & & & & & & & & $\checkmark$ & $\checkmark$ \\
\hline $\begin{array}{l}\text { Learnerships' are an important } \\
\text { element of the South African } \\
\text { government skills development } \\
\text { strategy. }\end{array}$ & & & $\checkmark$ & & & $\checkmark$ & $\checkmark$ & $\checkmark$ & & $\checkmark$ \\
\hline $\begin{array}{l}\text { Mentoring plays a significant role in } \\
\text { work-based learning, as well as at } \\
\text { post-graduate level. }\end{array}$ & & $\checkmark$ & $\checkmark$ & & $\checkmark$ & & & $\checkmark$ & & \\
\hline Learning is accelerated when real & & & & & $\checkmark$ & & $\checkmark$ & & $\checkmark$ & $\checkmark$ \\
\hline $\begin{array}{l}\text { Work-based learning offers learners } \\
\text { the opportunity to clarify their } \\
\text { career choice. }\end{array}$ & & & & & & & & $\checkmark$ & & $\checkmark$ \\
\hline $\begin{array}{l}\text { Educators and mentors should } \\
\text { always take into consideration that } \\
\text { although they are synchronously in } \\
\text { a situation with learners from } \\
\text { another generation their world- } \\
\text { views are dissimilar to those of the } \\
\text { learners. }\end{array}$ & & & & & & & & $\checkmark$ & & \\
\hline
\end{tabular}

With regard to the importance of collaboration between enterprises and educational institutions participant $\mathrm{J}$ declares that

"institutions have their curriculum outlined and corporate world has certain expectations, but the two do not really meet, however, we experienced that we could sit down with the staff and tell them what we as an organisation need". 
Participant A proclaims,

"programmes developed specifically for industry ... came about as result of the inflexibility of the institution's formal programmes in relation to the changing needs in the market".

Participant A asserts that inflexible national educational structures do not accommodate rising industry needs and mentions that "one of the biggest problems currently in South Africa is the inflexibility of formal programmes". Participant G experiences institutions as inflexible and remarks that

"[u]nfortunately the technikons do not see the urgency as the companies see it, technikons are quite happy to carry on until they hit a brick wall and then they change".

Participant A motions that "a culture of entrepreneurship needs to be established at Higher Education institutions" and a consulting mindset espoused among academics. Participant A explains that the curriculum of formal programmes may serve as 'spine' or broad mental framework with which to approach the client. This idea is echoed by the views of participant F.

According to research participants the functioning of technikon advisory committees leaves a lot to be desired.

Participant H observes:

"[a] diverse grouping of people, representing diverse organisations, attends [a advisory committee meeting] and needs to arrive at decisions, as a result people waffle" and often experiences that the "attendees of advisory committee meetings as being ill informed about preceding actions".

It appears that advisory committees primarily serve the purpose of sharing technikon information with commerce and industry. It is the experience of participant $G$ that advisory committees primarily serve the purpose of sharing technikon information with commerce and industry. Participant E corroborates this by acknowledging that although an advisory committee exists for their programme it "[s]ometimes meets once a year or once every two years, you tell industry what you are doing and they say great!" Participant E admits that the interaction has not been close and that involvement should be closer.

From the data collected it is evident that the CTP's ideals with regard to the functioning of advisory committees, do not necessary materialise. However, in contrast, participant B (university-based) claims that regarding their research advisory board "members are consulted in the research strategy of the departments involved and what needs to be researched".

Participant B submits that " $[\mathrm{t}]$ he principle of work integrated learning is laudable and the concept is sound" but that "[s]ignificant industry experience at under-graduate level is practically problematic". And further:

"[a]n extremely sensitive and willing industry partner is necessary to make reaching out activities, practical projects and vacation work successful" and observes that "the success of learning from work experience is fully dependent on the fact if an industry partner is supportive and available, that has the time and energy at management level to make this learning happen".

Participant D finds that "the institution struggles to place students". Their experience is that "employers no longer want to take students, due to resource constraints, mainly no longer having money to remunerate students but also not having people available/willing to mentor students".
Participant G complains, "there is a big gap between the tertiary institutions and business with regard to what is expected and what happens in experiential learning". With regard to the monitoring of experiential learning, participant $G$ further observes that the institution sends

\begin{abstract}
"somebody out once during a semester to interview, talk about and see if experiential learning takes place correctly ... students are essentially cheap labour ... training is consequential and production the purpose. There is a big deficiency".
\end{abstract}

When comparing the five scenarios (views of participants $\mathrm{C}$ and $\mathrm{D}$ that are institution-based, and participants $\mathrm{F}, \mathrm{G}$ and $\mathrm{I}$ that are enterprise-based) to the fundamentals of co-operative education, only participant F's scenario represents good cooperative education practice. Only the scenarios of participants $\mathrm{F}$ and $\mathrm{J}$ are indicative of managed integration of theory and practice. It is important to note that both are enterprise-based. Instead, one would have expected that the views of institution-based participants would have reflected good co-operative education practice.

Both participants $\mathrm{I}$ and $\mathrm{J}$ remarked that in-service training programmes offer enterprises the opportunity to get to know the performance of people in training. This knowledge enables enterprises to make informed choices regarding who to consider for future employment. Participant J takes pride in saying " $[\mathrm{w}] \mathrm{e}$ created a talent pool, if there is a vacancy we know whom to employ" and asserts that "[w]e further do not have to use strangers because we know that we already have a pool of people". The money that would have been spent on recruiting is rather spent on training.

\section{Participant $\mathrm{H}$ professes that}

"learnerships are part of the national skills strategy, which is about human development ... [it is] the vehicle (karretjie om mee te ry) ... learnerships offer certain incentives from government and opportunities for enterprises".

Participant G indicates that the "hot subject at the moment is learnerships" and particiapnt C asserts that in-company programmes, which are still very popular in South Africa, are gaining interest from Sectoral Education and Training Authorities (SETAs). Particiapnt F claims that certificates issued by enterprises are no longer adequate, people want more substantial acknowledgement, which a learnership qualification offers. Participant $G$ believes that it is feasible to convert an existing formal qualification to unit standards and that it can then become a learnership, which will make it easy for an enterprise to recover bursary funding and increase available opportunities.

Mentoring and mentorship come into play in educational programmes with the application of the theory studied and how the theory is applied in reality, according to participant $\mathrm{H}$, who states "it brings out the "know how' of a person". This 'know how' (or talent) represents the person's value to an employer. Regarding the importance of mentors, participant $\mathrm{C}$ states

"mentors play a significant role ... they are expected to fulfil their role as mentor or face the possibility of being surpassed by the would-be mentee ... this keeps mentors on their toes ... requirements include both theoretical know-how and practical competence ... the mentor facilitates the experiential learning of participants".

Regarding the importance of the mentor in the work-based learning setting, participant E remarks "[y]ou have to evaluate the mentor as well, because if you place a third year student in a company the mentor should be adequately experienced and qualified". At post-graduate level, according to participant B, it is often the practice that 
"[t]he participant has a study leader (academic person at university) and a mentor, in industry. The mentor considers the relevance of what is taught, if it addresses the problems experienced in industry, and if what is taught is applicable".

It is important that the reader realises that this type of research differs from other postgraduate research conducted at universities in that it is concerned with truth ('die waarheid').

\section{Participant E reinforces that}

"co-operative education is an educational model that integrates classroom theory with real-life work placements. To be most effective, a work placement has to be managed by the educator and not just something left up to the company".

Participant $\mathrm{G}$ remarks that it is their experience as employer that

"students during the first half of their experiential leaning do not contribute much, they are very raw and do not know anything. They do very basic stuff. During the second half they are very productive. The money spent on them is a good return on investment. However, the value of the individual depends very much on her/his own curiosity and drive. Some require pushing".

With regard to the second year of company-specific training and the productivity of in-service trainees during the second half, participant I declares that " $[\mathrm{a}] \mathrm{n}$ in-service training student becomes fully a member of a design or pilot campaign, which is carefully thought out". Participant J points out the unfortunate reality that people from disadvantaged communities often do not have access to gaining work experience.

\section{Participant J emphasises that}

"Students partaking in a joint venture programme are really advantaged because they can see if this is what they really want. They can see is what they will really be going through when they completed their degree, diploma or certificate".

With regard to the matter of choices participant $\mathrm{H}$ presents a personal theoretical construct which he calls 'synchronous dissimilarity' (gelyktydige ongelykheid). He asserts that different generations are simultaneously in the same time frame but are dissimilar ('synchronous dissimilarity') with regard to values and approach to work, learning and life. He emphasises that when growing talent through collaboration between educational institutions and employers, it should be taken into consideration that the world-views of learners are likely to be different from those of the educators or trainers.

\section{Perspectives of programme participants}

In one case, 29 learnership participants wrote essays about their points of view, feelings about and/or perspectives on the programme they were undergoing. In another case four participants wrote essays and three participated in a focus group interview. Many express a great deal of optimism and gratitude, whereas others indicate some measure of stress, and a few express pessimism or convey criticism. The word "talent" was used spontaneously in three essays. Selected perspectives are:

The programme is considered a great opportunity for people seeking to take up a particular career.

- The programme "gives young people hope for the future" in that it helps learners to obtain tertiary qualifications from reputable institutions Employers look for people with experience, which a learnership offers.

- The programme gives you an opportunity to realise your God-given potential and talent.
- The programme is a talent scout to society as a whole, but more specifically benefits the most under-privileged people, who cannot afford to learn and need assistance. The programme helps to improve the well-being of society.

- The system of learnerships, where employers and educational institutions work together, should be taken down to school leavers to jumpstart their careers and to help those people with the love for and talent towards a specific job.

- The programme exposes one to many things, including the employer, the educational institution, team-building, getting to know yourself and your capabilities, grooming, discipline, responsibility and the drive to work hard. Participants are most fortunate.

- The programme "prepares us for times ahead when we will actually be involved in the workplace".

- The programme is very good, but stressful with regard to all the things that need to be learned. The programme offers opportunities to practise what you have been taught. You acquire good communication and telephone skills, as well as knowledge of e-mail, and you learn good grooming and how to dress for work.

- You are learning under pressure, and you learn about time management and the more efficient use of time.

- Employers should pay attention to the way they inform their staff about the learnership programme, as some departments were disorganised.

- Too much time is spent in some departments, as it is possible to understand what is going on in a shorter period.

- The programme schedule makes provision for lectures and working experience only, not for study time, for which provision should be made. Guidance and supervision in the workplace are further lacking, and there should be dedicated staff in each department to teach students.

The stress related to working late or night shifts and the restrictions that this places on study time make the programme difficult, especially if one is writing an examination the following day. Concerns were also expressed about safety if working abnormal hours.

The examination performance expectations set by the employer are threatening and create anxiety. Participants sometimes felt like leaving the programme.

"[A]part from the technical skills that some subjects are offering me I learn a lot on how to work with people". The participant felt that the technikon programme is far better than some purely academic programmes in that it shaped him/her to be a professional person able to slot into a strategic management, planning, and even admin-related position in addition to performing purely technical duties, "thus making me extremely versatile, flexible and giving me a solid enough base to expand on in future".

"I have basically earned all my practicals at work ... it has been quite embarrassing for me when I couldn't do the most basic things ... [i]t's a very sad situation when you meet other students from other institutions having a clear understanding of basic stuff ...".

"The experience and training that I have been privileged enough to receive [where I worked] has been invaluable ... I firmly believe that I learned more about the $[\mathrm{xx}]$ field in the 8 months that I have been [working] than I learned in $2 \frac{1 / 2}{2}$ years at [the technikon]".

\section{DISCUSSION}

The ten participants interviewed (five education institutionbased programme managers and five enterprise-based representatives) shared a comprehensive range of perspectives. From these shared perspectives, although the findings cannot 
be generalised, one may conclude with some confidence that co-operative education has the potential to serve as an educational paradigm to grow the talent of people in South Africa. However, from these perspectives it seems also reasonable to conclude that there are currently several shortcomings and/or restraining factors with regard to the practice of co-operative education.

From this study, it is clear that not all programme participants are equally satisfied; some are more satisfied than others. In order to optimise the learning of those programme participants who are less satisfied, appropriate interventions are recommended, such as for example making the necessary arrangements that programme participants do not work nightshift prior to a test. Other interventions may include stress management training by the institution's student counselling services. From the perspectives of participants it is further evident that the logistical organisation and co-ordination of programmes may require improvements.

However, we also found that bureaucratic processes refute the core principles of co-operative education. These bureaucratic processes obstruct needs-focused (where experiential learning is integrated) curriculum design. We further found that advisory committees do not function the way they are intended.

We found that major difficulties are experienced in finding sufficient experiential learning placement opportunities for students. It appears that supportive and reliable partners are crucial and must be nurtured. Learnerships appear from the findings of this study to be exemplary of good co-operative education practice.

It is important to note that the benefits derivable from experiential learning are largely undermined, according to the research findings, as a result of inadequate arrangements, co-ordination and monitoring. From the findings it is clear that the appropriate level of supervision and/or mentoring of experiential learners is a key to the success of co-operative education

On a more positive note, co-operative education programmes are instrumental in creating a talent pool, and afford programme participants the opportunity to clarify their career choices by being exposed to workplace realities.

From a limited degree of data triangulation that was feasible, it is clear that the notion of an integrated curriculum is highly valued by co-operative education programme participants, but that the organisational logistics may be problematic.

The qualitative research findings and literature review of the present study are of importance to four clusters of bodies:

(a) For the Rand Afrikaans University's Centre for Work Performance. The findings address one of the major issues identified by the centre for resolution: the growing of talent. The literature review and findings of the present study are of considerable value to the endeavours of enterprises that are seeking ways to enhance their efforts in growing the talent of their people and should form part of the literature sources of the centre.

(b)For the technikon sector of Higher Education in South Africa. The qualitative research findings are of importance to the Committee of Technikon Principals (CTP) and technikon management, because the findings question the CTP's assumptions regarding the practice of co-operative education by technikons in Gauteng. The findings further suggest an inefficacy of technikon education.

The findings are of importance to the Department of Education (DoE), the Council on Higher Education (CHE), South African Qualifications Authority (SAQA) and the CTP, because the findings suggest that the national process with regard to the approval of technikon qualifications is counterproductive to needs-focused education by technikons.

(c) For the national role players in the position to amend the Skills Development Levies Act. The findings and literature review are of importance to the Department of Labour (DoL), DoE, the South African Revenue Services (SARS) and the National Treasury in view of the contemplated amendments to the Skills Development Levies Act to make provision for funding co-operative education programmes.

The findings and literature review are of importance to DoL, the various Sectoral Education and Training Authorities (SETAs) and professional bodies, because of the valuable contribution regarding the design and improvement of learnerships and similar co-operative education programmes.

(d) For the national government role players involved in the national human resources development (HRD) strategy. The findings and literature review are of importance to the South African national government and associated role players (for example, Dol, DoE, commissions such as the Black Economic Empowerment Commission, political parties, etc.) with regard to the national HRD strategy, skills development policies, etc.

From the positive experiences of research participants about joint educational ventures and/or the perceived value derived from collaborative efforts, it can be concluded that cooperative education presents itself as an educational strategy to enable Higher Education institutions to contribute significantly to the talent growth required among the people of South Africa.

\section{REFERENCES}

Accreditation Council for Cooperative Education. (n.d.). College and university program attributes. Retrieved April 24, 2002 from: http://www.co-opaccreditation.org/attribut.html.

Arksey, H \& Knight, P. (1999). Interviewing for social scientists. London: Sage.

Babbie, E. (1995). The Practice of Social Research. $7^{\text {th }}$ edition. Belmont, Calif.: Wadsworth.

Bailey, C.A. (1996). A guide to field research. Thousand Oaks, Calif.: Pine Forge.

Bals, T. (1999). Fostering talents in vocational training: current strategies in Germany. High Ability Studies, 10 (1), 97-105.

Barner, R. (2000). Talent Wars in the executive suite. Futurist, $34(3), 35-41$.

Barnes, N.J. \& Phillips, P.S. (2000). Higher Education partnerships. International Journal of Sustainability in Higher Education, 1 (2), 182-190.

BEE Com. see Black Economic Empowerment Commission.

Bentz, V.M. \& Shapiro, J.J. (1998). Mindful enquiry in Social Research. Thousand Oaks, CA: Sage.

Berkeley, J. (1998). Promoting lifelong learning through education partnership: part 1. Education \& Training, 40 (6/7), 256-261.

Black Economic Empowerment Commission. (2001). BEE Com. Report. Johannesburg: Skotaville.

Blackburn, P \& Fryer, B. (1996). An innovative partnership in management development. Management development review, 9 (3), 22-25.

Bless, C. \& Higson-Smith, C. (2000). Fundamentals of social research methods, an African perspective. $3^{\text {rd }}$ edition. Lansdowne: Juta.

Bloor, M. (1997). Techniques of validation in qualitative research: a critical commentary. In Millar, G. \& Dingwall, R. (eds.) (1997). Context and Method in Qualitative Research (pp. 37-50). London: Sage.

Brindley, C. \& Ritchie, B. (2000). Undergraduates and small and medium-sized enterprises: opportunities for a symbiotic partnership? Education \& Training, 42 (9), 509-517. 
Caelli, K. (2001). Engaging with phenomenology: is it more of a challenge than it needs to be? Quantitative Health Research, 11 (2), 273-282.

Cameron, M.E., Schaffer, M. \& Hyeoun, P. (2001). Nursing students' experience of ethical problems and use of ethical decision-making models. Nursing Ethics, 8 (5), 432-448.

Cataldo, P., Van Assen, J \& D'Alessandro, A. (2000). How to win the telecom talent war. America's Network, 104 (11), 55-58.

Cates, C. \& Jones, P. (1999). Learning outcomes - the educational value of cooperative education. Maryland: Cooperative Education Association.

Coffey, A \& Atkinson, P. (1996). Making sense of qualitative data, complementary research strategies. Thousand Oaks: Sage.

Conway, C. (1995). Mentoring in the mainstream. Management Development Review, 8 (4), 27-29.

Crabtree, B.F. \& Miller, W.L. (eds.) (1992). Doing qualitative research. Research methods for primary care, Volume 3. Newbury Park: Sage.

Creswell, J.W. (1994). Research design, qualitative and quantitative approaches. Thousand Oaks: Sage.

Creswell, J.W. (1998). Qualitative inquiry and research design, choosing among five traditions. Thousand Oaks: Sage.

Cross, L. (1999). Grooming management talent. Graphic Arts Monthly, 71 (9), 93-96.

Davidson, J. (2000). A phenomenology of fear: Merleau-Ponty and agoraphobic life-worlds. Sociology of Health \& Illness, 22 (5), 640-681.

Davies, D.W. (1998). Beyond the boundary: the learner perspective in WBL. Journal of Workplace Learning, 10 (3), $152-156$

Dealtry, R. (2001). Managing the transition to the corporate university - a synthesis of client research. The Journal of Workplace Learning, 13 (5), 215-222.

Denzin, N.K. \& Lincoln, Y.S. (eds.) (2000). Handbook of qualitative research. $2^{\text {nd }}$ edition. Thousand Oaks: Sage.

Denzin, N.K. \& Lincoln, Y.S. (eds.) (1998). The landscape of qualitative research, theories and issues. Thousand Oaks: Sage.

Doherty,N., Viney, C. \& Adamson, S. (1997). Rhetoric or reality: shift in graduate career management? Career Development International, 2 (4), 173-179.

Doncaster, K. (2000). Learning agreements: their function in work-based programmes at Middlesex University. Education \& Training, 42 (6), 349-355.

Duwart, E.J. \& Canale, R.L. (1997). Re-engineering cooperative education learning. Industry \& Higher Education, 11 (4), 229235.

Education for an 'African renaissance'. (2000). Africa Recovery, 14(2), 14. Retrieved April 7, 2002 from: http://www.un.org/ ecosocdev/geninfo/afrec/subjindx/142educ6.htm.

Ellison, C. (N.d.). Cooperative Education at University of Cincinnati. Retrieved December 22, 1999 from: http://www.daap.uc.edu/SOP/sop_programs/Cooperative_E ducation.html.

El-Tannir, A.A. (2002). The corporate university model for continuous learning, training and development. Education \& Training, 44 (2), 76-81.

Eshbach, O.W. (1947). Co-operative courses and their place in a university. In: University of Cincinnati. (1947). Four decades of the co-operative system. Fortieth anniversary program, October 16, 1946, with addresses and additional facts on the founding and development by Herman Schneider of the co-operative system of technological education. Cincinnati, Ohio: Cincinnati University Library.

Ferris, B. (1969). Cooperative education: neglected winner. Journal of Higher Education, 40 (6), 480-483.

Figura, S.Z. (2000). Human capital: the missing link. GovExec.com, March 1. Retrieved February 16, 2002 from the World Wide Web: http://www.govexec.com/gpp/0300hr.htm.

Finn, K.L. (1997). The spaces between: toward a new paradigm for cooperative education. Journal of Cooperative Education, $32(2), 36-45$
Fouche, F. (1993). Phenomenological theory of human science (pp. 87-112). In Snyman, J. (ed.) (1993). Conceptions of social inquiry. Pretoria: Human Science Research Council.

Fourie, P. (n.d.). The African renaissance and technology transfer. Retrieved April 7, 2002 from: http://www.geocites. com/CollegePark/Square/6130/olvol03/fourie.htm.

Freedland, M. (2000). The talent wars. Professional Builder, 65 (1), $175-176$.

Freund, C.J. (1947). The philosophy of the co-operative system. In: In: University of Cincinnati. (1947). Four decades of the cooperative system. Fortieth anniversary program, October 16, 1946, with addresses and additional facts on the founding and development by Herman Schneider of the co-operative system of technological education. Cincinnati, Ohio: Cincinnati University Library.

Furco, A. (1996). Service-learning and school-to-work: making the connections. Journal of Cooperative Education, 32 (1), 7-14.

Garavan, T.N., Morley, M, Gunnigle, P. \& Collins, E. (2001). Human capital accumulation: the role of human resource development. Journal of European Industrial Training, 25 $(2,3,4), 48-68$.

Geier, F.V. (1947). The co-operative system and industry. In: University of Cincinnati. (1947). Four decades of the cooperative system. Fortieth anniversary program, October 16 , 1946, with addresses and additional facts on the founding and development by Herman Schneider of the co-operative system of technological education. Cincinnati, Ohio: Cincinnati University Library.

Gericke, J.S. (2001). Companies, colleges team up to develop talent. Aviation Week \& Space Technology, 154 (12), market supplement, 24-27.

Greig, A. \& Taylor, J. (1999). Doing research with children. London: Sage.

Greene, M. (1997). The lived world, literature and education (pp. 169-190). In Vandenberg, D. (ed.) (1997). Phenomenology \& education discourse. Johannesburg: Heinemann.

Greene, M.V. (2000). War for talents greets graduates with IT skills. The Black Collegian, 3 (1), 80.

Hadland, A. \& Rantao, J. (1999). The life and times of Thabo Mbeki. Rivonia: Zebra.

Hammett, S. (2001). Agents pay more to win war for talent. National Underwriter, October, 24-25.

Hammersley, M. (2000). Taking sides in social research. London: Routledge.

Holloway, I. (1997). Basic concepts for qualitative research. Oxford: Blackwell Science.

HRfocus see Retention.

Hycner, R.H. (1999). Some guidelines for the phenomenological analysis of interview data (pp. 143-164). In Bryman, A \& Burgess, R.G. (eds.) (1999). Qualitative research. Volume III. London: Sage.

James, J.A. (1997). The idea of an African Renaissance: myth or reality. In the General Convention of the Alpha Phi Alpha Fraternity. Washington, D.C. Retrieved April 7, 2002 from: http://usembassy.state.gov/posts/sf1/wwwhjj12.html.

Johnson, M. (2000). Wining the people wars. London: Prentice Hall.

Johnson, S.K., Geroy, G.D. \& Griego, O.V. (1999). The mentoring model theory: dimensions in mentoring protocols. Career Development International, 4 (7), 384-391.

Kensit, D.A. (2000). Rogerian theory: a critique of the effectiveness of pure client-centred therapy. Counselling Psychology Quarterly, 13 (4), 345-342.

Kerka, S. (1999). New directions for cooperative education. Eric Clearinghouse on adult career and vocational education, Columbus, OH. Eric Digest No 209. Retrieved April 25, 2002 from: http://www.ed.gov/databases/ERIC_Digests/ed434245. html.

King, N. (1994). The qualitative research interview. In Cassell, C. \& Symon, G. (eds.) (1994). Qualitative methods in organisational research, a practical guide. London: Sage. 
Kruger, D. (1988). An introduction to phenomenological psychology. $2^{\text {nd }}$ revised edition. Cape Town: Juta.

Kvale, S, (1996). Interviews, an introduction to qualitative research interviewing. Thousand Oaks: Sage.

Lauer, Q. (1958). Phenomenology, its genesis and prospects. New York: Harper.

Liebmann, L. (2000). The only real "core competency" is growing talent. Computerworld, May 1, 33.

Langford, D. \& Cates, C. (1997). Co-operative education as a means of developing general education skills. Retrieved unknown date from: http://fairway.ecn.purdue.edu/v1/asee/ sect95/4A/4A5.html.

Lunn, T. (1995). Selecting and developing talent: an alternative approach. Management Development Review, 8 (1), 7-10.

Maloka, E.T. (n.d.). The South African 'African Renaissance' debate: a critique. Retrieved April 7, 2002 from: http://www.cean.u-bordeaux.fr/polis/vol8n5/moloka.pdf.

Mamdani, M. (1999). There can be no African Renaissance without an African-focused intelligentsia. In Makgoba, M.W. (ed.) (1999). African Renaissance the new struggle. Sandton: Mafube \& Cape Town: Tafelberg.

Managers Handbook see Mentoring: a crucial strategy.

Mason, J. (1996). Qualitative researching. London: Sage.

Matthew, L. (2000). Your strategy for the talent war. Management Today, October, 106-111.

Mayo, A. (2000). The role of employee development in the growth of intellectual capital. Personnel Review, 29 (4), 521-533.

Maypole, J. \& Davies, T.G. (2001). Students' perceptions of constructivist learning in a community college American History II ... Community College Review, 29 (2), 54-80.

Mbeki, T. (1998). Statement by deputy president Mbeki at the African Renaissance conference, September 28, 1988. Retrieved April 7, 2002 from: http://www.anc.org.za/ ancdocs/history/mbeki/1998/tm0928.htm.

McDonald, L. (1999). Fighting the talent war. Best review: Property-Casualty Insurance Edition, 99 (8), 8.

Mentoring: a crucial strategy. (1997). Managers Handbook, 2 (3), 12.

Miller, W.L. \& Crabtree, B.F. (1992). Primary care research: a multimethod typology and qualitative road map. In B.F. Crabtree \& W.L. Miller (eds.) (1992). Doing qualitative research. Research methods for primary care, Volume 3. Newbury Park: Sage.

Moustakas, C. (1994). Phenomenological research methods. Thousand Oaks: Sage.

Mouton, J. \& Marais, H.C. (1990). Basic concepts in the methodology of the social sciences. Revised edition. Pretoria: Human Sciences Research Council.

Mulemfo, M.M. (2000). Thabo Mbeki and the African Renaissance. Pretoria: Actua.

Netshitenzhe, J. (1998). The media in the African Renaissance. In the African Renaissance Conference. Retrieved April 7, 2002 from: http://www.gcis.gov.za/media/joel/media.htm.

Pratt, P M. (1996). Earn and learn through cooperative education. Retrieved December 22, 1999 from: http://www.environs. com/talbot/learn1.html.

Radebe, J. (2001). The South African government's vision for the African Renaissance and African unity: contextualising the policy. In African Unity and Revival: A vision for the Millenium Conference. Moscow: Russian Federation. Retrieved April 7, 2002 from: http://www.dpe.gov.za/ docs/sp/2001/sp1002.html.

Rand Afrikaans University. (2002). Centre for Work Performance. Current burning issues. Retrieved February 11, 2002 from: http://general.rau.ac.za/cwp/current_burning issues/current_burning_issues1.htm.

Republic of South Africa. (2001). Department of Education. Human resource development strategy for South Africa a nation at work for a better life for all. Retrieved April 28, 2003 from: http://www.udw.ac.za/merger/ documents.htm, or alternatively from: http://education.pwv. gov.za/Policies\%20and\%20Reports/2001_Report/reports_200 1.htm.
Republic of South Africa. (2000). African Renaissance and International Co-operation Fund Act 51 of 2000. Pretoria: Government Printers.

Retention. (2001). Six ways to win the talent wars. HRfocus, 78(6): 1, 14-15

Reuss, P.B. (2001). Students reap the benefits from facultyemployer connection. Journal of Career Planning \& Employment, 61 (3), 37-39.

Ridderstråle, J. \& Nordström, K. (2000). Funky business, talent makes capital dance. Harlow: Bookhouse.

Robinson, D. \& Reed, V. (eds.) (1998). The A - Z of social research jargon. Aldershot: Ashgate.

Rosenbaum, D.B. (2000). Concern about talent shortage leads industry into classrooms. Engineering News Record, 254 (17), 44-51.

Sadala, M.L.A. \& Adorno, R.deC.F. (2001). Phenomenology as a method to investigate the experiences lived: a perspective from Husserl and Merleau Pontt's thought. Journal of Advanced Nursing, 37 (3), 282-293.

Sandelands, E. (1998). Developing a robust model of the virtual corporate university. Journal of Knowledge Management, 1 (3), 181-188.

Seligman, M. (2000). The talent wars. Management, 47 (9), 52-57.

Schurink, W.J. (2002a). Introduction. Unpublished introductory lecture notes of a qualitative workshop for doctoral and masters students, 5 April 2002, Department of Human Resource Management. Johannesburg: Rand Afrikaans University.

Schurink, W.J. (2002b). Core features of qualitative research. Unpublished lecture one notes of a qualitative workshop for doctoral and masters students, 5 April 2002, Department of Human Resource Management. Johannesburg: Rand Afrikaans University.

Schwandt, T.A. (1997). Qualitative inquiry, a dictionary of terms. Thousand Oaks: Sage.

Shoebridge, N. (2000). Strategies for the talent war. Business Review Weekly, 22 (32), 10.

Simonton, D.K. (2001). Talent development as a multidimentional, multiplicative, and dynamic process. American Psychological Society, 10 (2), 39-43.

Smith, B.W. \& Lancaster, A-M. (1995). The growth in commitment to cooperative education in a computer science program. Journal of Studies in Technical Careers, XV (2), 71-79.

Smith, A. \& Smith, B. (1990). A successful development partnership. Industrial \& Commercial Training, 22 (6), 3-8.

Sovilla, E.M. (1998). Co-op's 90-year odyssey. The American Society for Engineering Education [ASEE] Prism, January, 18-23. Retrieved December 22, 1999 from: http://www. asee.org/pubs/html/coop.htm

Stephen, J., Jones, P. \& Huntington, S. (1997). Pre-placement work-based projects within a retail sandwich degree. Industrial and Commercial Training, 29 (2), 49-52.

Street, A. (1998). In/forming inside nursing: ethical dilemmas in critical research. In Shacklock, G. \& Smyth, J. (1998). Being reflective in critical educational and social research. London: Falmer.

Stones, C.R. (1988). Research: toward a phenomenological praxis (pp. 141-156). In Kruger, D. (1988). An introduction to phenomenological psychology. $2^{\text {nd }}$ revised edition. Cape Town: Juta.

Sunoo, B.P. (2001). HR scouts recruit, develop and retain talent at PR agency. Workforce, March: 46-47.

Teare, R. (2000). Modelling the virtual university. The Journal of Workplace Learning, 12 (3), 111-123.

Tulgan, B. (2001). Winning the talent wars. Employment Relations Today, 28 (2), 37-51.

United States of America. (2000). National Aeronautics \& Space Administration [NASA]. Human resources and education: functional leadership plan. Retrieved February 16, 2002 from: http://www.hq.nasa.gov/office/codez/plans/FLPs/FFLP.pdf. 
United States of America. (1914). House of Representatives. Committee on Education. Cooperative system of education vocational education. In a hearing before the Committee on Education, statement by Mr Herman Schneider. Sixty-third congress, second session, on 26 January 1914. Washington: Government Printing Office.

University of Cincinnati. (1996). Division of Professional Practice. Historical View. Retrieved December 22, 1999 from: http://www.uc.edu/propractice/history.html.

University of Cincinnati. (1998). Department of Civil and Environmental Engineering. Retrieved December 22, 1999 from: Co-op. http://www.cee.uc.edu/coop/coop.htm.

University of Witwatersrand. (1999). Graduate School for Humanities and Social Sciences. Thinking through the African renaissance. Retrieved April 7, 2002 from: http://www.wits.ac.za/fac/arts/african /archive/afr.html.

Van Manen, M. (1997). Phenomenological pedagogy and the question of meaning (pp. 41-68). In Vandenberg, D. (ed.)
(1997). Phenomenology \& education discourse. Johannesburg: Heinemann.

Vicere, A.A. (1991). The changing paradigm for executive development. Journal of Management Development, 10 (3), 44-47.

Voros, S.V. (1999). Winning the talent wars with smart recruiting. Business Press, 12 (3), 25-26.

Way, N. (2000). Talent war. Business Review Weekly, 22 (32), 6470 .

Welman, J.C. \& Kruger, S.J. (1999). Research methodology for the business and administrative sciences. Johannesburg: International Thompson.

Wilson, J.W., Stull, W.A. \& Vinsonhaler, J. (1996). Rethinking cooperative education. Journal of Cooperative Education, 31 (2 \& 3), 154-165.

Ziarati, R., Griffiths, J., Bennett, M. \& Payne, P. (1995). University of Central England-Rover partnership. Logistics Information Management, 8 (6), 8-12.

Zinker. J. (1978). Creative process in gestalt therapy. New York: Vintage. 